\title{
FACING CHILD SOLDIERS, MORAL ISSUES, AND "REAL SOLDIERING": ANTHROPOLOGICAL PERSPECTIVES ON PROFESSIONAL ARMED FORCES*
}

\author{
Eyal Ben-Ari
}

\author{
The Hebrew University of Jerusalem
}

\section{Introduction}

In today's world, adolescents and children sometimes act as combatants who directly participate in hostilities. Yet more often they are deployed as auxiliaries (for example, as lookouts or messengers) or in various support roles (as gardening, road maintenance, delivery of food, cleaning, cooking, conveying goods and providing sexual services) (Boothby and Knudsen 2000). Finally, under certain circumstances, adolescents and children may be used as human shields or for propaganda purposes by government or opposition forces (Boyden and De Berry 2004:xii; United Nations 2002:13). Since the late 1970s, a number of international conventions have been promulgated to limit the use of these young people, but children continue to be deployed in parts of the world and overwhelmingly in sub-Saharan Africa. Estimates as to their numbers vary. Human Rights Watch (2007), a human rights lobby, estimates that there are between 200000 and 300000 such youngsters in armed conflicts in over twenty countries. Amnesty International (2007), another such organisation, estimates,

With new weapons that are lightweight and easy to fire, children are more easily armed, with less training than ever before. Worldwide, more than half a million children under-18 have been recruited into government armed forces, paramilitaries, civil militia and a wide variety of non-state armed groups in more than 85 countries. At any one time, more than 300 000 of these children are actively fighting as soldiers with government armed forces or armed political groups.

In addition, there are various estimates as to the age of the youngest child soldiers with Nordstrom (2004) documenting an eleven-year-old, Human Rights Watch declaring that some are as young as eight years old, Amnesty International 
offering that some are younger than ten years of age, and Singer (in Brookings Institute 2007) contending that some are as young as seven. In countries that are already poor, war tends to deteriorate economic and social conditions, thereby forcing families into further economic hardship. As a result, children may join armed forces or groups to secure daily food and survival (Honwana 2001:128).

In one of the most comprehensive and careful overviews of the subject, Boyden (2006:3) cautions that it is quite "ludicrous to talk about child soldiering as an 'epidemic' on the basis of speculative UN figures indicating that the world's military arena at present contains a mere 250,000 [such young] combatants and support personnel under the age of 18." In fact, it appears "that in most places other than sub-Saharan Africa the number of child soldiers is decreasing and that even in sub-Saharan Africa the evidence of marauding hordes of alienated, angry and aggressive youth simply does not exist". This appraisal is echoed by a recent United Nations (2005) report that admits that the number of child soldiers is declining.

But what happens when soldiers belonging to professional armed forces face these young combatants? Such potentially violent engagements can be devastating for such troops. Thus for example, in commenting about the U.S. forces, Singer (2003:29) contends that children are not seen as hated enemies and -

U.S. soldiers usually exhibit a great amount of empathy toward children in war-torn societies. Consequently, engagements with child soldiers can be incredibly demoralizing for professional troops and can also affect unit cohesion. For example, there was little official dilemma or controversy over Allied actions against the Hitler Jugend in 1945. The youths were seen as fighting to defend an absolutely evil regime, and that general agreement among the allies was that Hitler's regime had to be completely defeated. Yet the experience of fighting against the Jugend was so unsettling to U.S. Armed Forces that troop morale fell to some of the lowest points in the entire war. Likewise, British forces operating in West Africa in 2001 faced deep problems of clinical depression and posttraumatic stress disorder among individual soldiers who had faced child soldiers.

Along these lines, as Meijer (2007) makes clear, a number of people have documented the psychological burdens of facing child soldiers. Against this background, I propose to offer an anthropological perspective on the effects of confronting child soldiers on troops of professional militaries who participate in various kinds of PSOs (peace-support operations). By an anthropological perspective I refer both to an analysis of the cultural contexts within which the label 
"child soldiers" is used and to an inquiry into how this socially constructed category may actually intensify the problems professional troops encounter in contemporary conflicts. Given the centrality of psychology or psychiatry as regards the study of such issues, I explicitly formulate my argument to complement their disciplinary perspective.

Let me outline my argument in short: My main contention is that, in order to understand the place of child soldiers as the opposing force, we need to "problematise" this category. To do so, we need to take into account three factors: the "folk" or "lay" model of soldiering that soldiers of professional militaries use to make sense of their actions; the changed global assumptions and images of children; and the activities of a host of organisations and movements that cultivate the imagery of child soldiers. Concretely, young fighters - and especially children as opposed to adolescents - present a cultural anomaly since children do not fit the interpretive frames or cognitive schemas of combat of troops. Culturally speaking, not only are children not "proper" military enemies, but, confronting them is experienced as an abnormal situation since such youngsters contravene assumptions and deeply held beliefs about children as innocent and vulnerable.

This situation is intensified by the images of child soldiers propagated by a loose coalition of media representatives, policy and decision-makers, (mainly psychological) researchers, security experts, human rights advocates and humanitarian activists. This diverse alliance tends to portray children in war as being at risk, with child soldiers being the very personification of hazards posed by armed conflict and social disorder. These images, in turn, resonate with the soldiers "on the ground" who sometimes face child soldiers. This coalition, moreover, is part of the global surveillance of military forces deployed around the world and which is now a prime factor making professional armed forces constantly open to external scrutiny and linking their missions to the process by which contemporary conflicts are judged on television screens and in newspaper columns. The combination of the stresses of armed combat, a posting outside of one's country, the anomaly of child soldiers, the emotional resonance related to confronting them, and the added pressures of global surveillance of military missions may lead to psychological problems that some soldiers express as a result of this situation.

In this respect, I think it important to underscore the ethical thrust of my argument. Let me be clear about one thing: the use of child soldiers is deplorable of prevalent practice in many conflicts around the world. One only has to read the constant flow of accounts from war zones to appreciate the horror and dismal experiences of these youngsters. At the same time, however, my argument is centred on the way much of public concern and condemnation is socially constructed by a 
wide coalition of cultural entrepreneurs. I do so not in order to detract from the importance of this phenomenon but rather to achieve two interrelated aims: first to clarify the complexity of the label of "child soldiers", and second to underscore the impact that imagery of child soldiers has on the perceptions and actions of professional soldiers facing them.

This article is based on my own research into the Israeli military and peacekeeping forces (Ben-Ari 1998; Ben-Ari, Michael and Kellen 2009), my work on childhood (Ben-Ari 1997), and on a careful reading of secondary literature based in a variety of disciplines. Concretely, this article is based on previous research on child soldiers and on a rich array of sources that include newspapers, journalistic observations, biographies and autobiographies, and websites for human rights and international bodies.

\section{Understanding child soldiers: Culture and agency}

Let me begin, following Boyden's (2006) seminal work, with a few observations about child soldiers from an anthropological point of view. Our understanding of child soldiers is marked by a rather particular disciplinary viewpoint that has been globalised over the past half a century or so. To put it simply, but not incorrectly, most of the literature on young people and the effects of war is based within "medicine, psychiatry, psychology and adheres to a biomedical paradigm" (Boyden and De Berry 2004:xii). The accepted wisdom within this broad coalition of disciplines is that the effects of war are overwhelmingly negative.

[S]ince it is generally thought that child development and wellbeing are based in biological and psychological structures that are fairly uniform across class and culture, children's responses are regarded as more or less the same everywhere. Much of the research also holds that the progression towards adulthood occurs in recognisable stages, early behaviors and experiences causally related to subsequent developmental achievements (Boyden and de Berry 2004:xiii)

The result of this kind of understanding is the assumption that children exposed to stressful war events are prone not only to traumatic reactions in both the shorter and longer term, but also to developmental impairment. I fully agree that given the highly destructive nature of armed conflict and the terrible suffering of children in such wars, it may seem self-evident that the dominant research focus on the psychopathological impact on children is the most appropriate one. But the problem is that such a perspective - that begins with questions assuming negative impacts may miss a broader range of effects on children and adolescents, such as the 
formation and maintenance of moral values, social competencies, and a sense of self-efficacy (Boyden and De Berry 2004:xv).

Take the title of Brett and Specht's (2004) book Young Soldiers: Why they Choose to Fight. As Hart (2006:7) suggests, this title hints at a willingness to accept that under 18-year-olds may join armed groups voluntarily rather than through coercion or abduction. However, the authors' view ultimately proves to be quite different. The authors draw on ideas about adolescence as a "time of vulnerability with the uncertainties and turbulence of physical, mental and emotional development", derived from the psychologist Erik Erikson, to account for their susceptibility to recruitment. By contrast, Honwana (2001:128-9), who has done work in Mozambique and Angola, states that some of the youngsters interviewed talked of their motivation to join armed conflict as arising out of the sense of security of possessing a gun and being able to defend oneself, an impulse to avenge the deaths of relatives, a sense of ethnic patriotism or ethnic grievance, or "the sheer fun and adventure of wearing military gear and carrying an AK-47". Indeed, Makinano (2002) also adds that some children encountered in the Philippines admitted that they joined militias for the "thrill and excitement". Furthermore, Gibbs (1994) and Dawes and Cairns (1998) caution that there is another side of Mozambican children, namely that they are strong as survivors (not victims) often actively growing up in difficult situations.

What would an alternative or complementary explanation of child soldiers consist of? From a broad anthropological point of view, I would stress three major points. The first relates to soldiering on the part of youngsters as consistent with local cultural categorisations or definitions. We must be wary of conflating chronological age with generational categories of childhood, adolescences and youth. Indeed, outside schools and sometimes work "chronological age is rarely a determinant of social categories and in many societies people do not celebrate their birth date and are not even aware of their age" (Boyden 2006:4). Vigh (2006), in his study of youths in Guinea-Bissau, found that what outsiders, such a journalists or members of humanitarian NGOs, understand under the translated word "child" in many cases refers to one's place in the generational scheme of elders and youngsters with some "children" being thirty years old. Richards (1996:174) observed that in Sierra Leone, combatants categorised by external observers as child soldiers from all the warring factions tended to share membership in an excluded and educationally disadvantaged youth underclass with no direct relation to their chronological age.

More recent ethnographic accounts of children in war tend to focus less on the process of socialisation and more on the ways in which social construction of childhood and war and the social transitions of aging predispose the young towards 
military action. One dominant theme in these analyses is the idea that the institution of war is not an aberration but that it somehow reinforces or replicates the ideational and structural forms that prevailed prior to its outbreak (Boyden 2006:17).

One expression of this form is the way recruitment into the military may be appealing to youngsters since it replicates and resonates with initiation rites into adulthood. Thus, as in many places in the world, becoming a soldier is a means for achieving adult status (Ben-Ari 2001; Morgan 1994; Badinter 1992; Arkin and Dobrofsky 1978). In addition, as a line of anthropologists have shown (Hutchinson 1996), within ethno-theories of human development in Africa and elsewhere, the young are sometimes framed as being especially well suited for warfare.

The second point centres on how leaders of armed groups appropriate cultural understandings for their own ends since there is a limit to cultural continuity because some violent episodes are truly inexplicable to both insiders and outsiders. In these cases, "agents in war co-opt social and cultural templates, employing them as rites of military induction, codes of military conduct and the structuring of relations within the military unit" (Boyden 2006:18). Shafer (2004), in her study of RENAMO combatants in Mozambique explains how the movement's commanders recognised that the separation from families was emotionally wrenching so they embraced a patriarchical imagery and the mantle of fictive kinship as a means to resocialise their young foot soldiers. The commanders became fathers and the troops became children and, along with associated incest taboos, these filial ties bestowed new loyalties on the troops and a firm obligation to serve their masters unquestioningly on the battlefield. In his autobiography, Beah (2007), a former child soldier from Sierra Leone, offers a similar portrait of the commander of his armed group. In such circumstances, one must not pathologise leaders of gangs of child soldiers and assert that they do not provide any moral guidance. I would suggest that they actually do provide such guidance but it is one centred on survival, images of manhood (and womanhood) and of loyalty and commitment to the fighting group as a family. To reiterate a point made earlier, I do not state this point to romanticise or naturalise the idea of child soldiers but to underscore the power of local cultural definitions in providing meaningful frames for recruitment into armed groups. Without an appreciation of such definitions we may well miss the diversity of actual phenomena encompassed by the broad category of "child soldiers".

The third, and most contested point, involves children as actors. An increasing number of researchers are working from a perspective that conceptualises young people's violence in war as the outcome of the dynamic interaction between constraining structural conditions and human agency. In other words, "youthful engagement in war is believed to be the consequence of structurally conditioned, 
motivated actions of volitional agents" (Boyden 2006:20). In less abstract terms, children and adolescents are seen as social actors who are engaged in rational, conscious, intentional action. This kind of view is related to wider perspectives about children in which such children are no longer conceived of as cultural dupes, empty vessels or passive recipients of socialisation (Hirschfeld 2002: 615; Fine 1988; Waksler 1986). Rather children are seen as actors with at least some power to resist and change the circumstances within which they live through bargaining and coalition-building based on the (albeit limited) powers of the weak. An excellent, if harrowing, example is provided by Beah (2007) who relates how he chose to join an armed group of child soldiers as a rational choice given the disintegration of most other communal structures in Sierra Leone.

Yet in most portrayals of child soldiers these capacities tend to be ignored. A United Nations (2002:12) report, for instance, states

in addition to being forcibly recruited, youth also present themselves for service. It is misleading, however, to consider this voluntary. While young people may appear to choose military service, the choice is not exercised freely. They may be driven by any of several forces, including cultural, social, economic or political pressures.

Brett (2002:2), writing about girls as soldiers, furthermore uses quotation marks with "voluntarily" to describe how these girls are recruited. So does Singer (2005:61) when he talks about a "less than 'voluntary' recruitment". And even Honwana (2001:129), who makes a strong case that in the terrible crises of Africa "parents can view their children joining either armed force - government or rebel as a form of protecting the children and themselves", does not see the actions of child soldiers as truly voluntary and places "child volunteers" within quotation marks.

However, Vigh (2006:50) writing about Guinea-Bissau suggests that if we see youngsters mobilised into militias as children we see them as mechanically mastered by their elders rather than as agents of war. Adopting his kind of view entails an engagement with young people as socio-political actors in a manner at odds with the broad thrust of current popular and academic depictions. Indeed, by suggesting that children may be intellectually and morally capable of engaging in political violence, Hart (2006:8) suggests that we question a basic premise of child-focused humanitarianism, namely that the young in situations of war are to be approached solely as victims. Even if coercion does play an important role in the recruitment of child soldiers, "the question is whether conceptualising child soldiering solely in 
terms of adult culpability and adult infractions is adequate to the task of explaining children's apparent predilection for violence" (Boyden 2006:8; Vogler 2006).

Against this background of youngsters taking up arms I move on to the main part of my text.

\section{The folk model of military units in professional forces}

What is the imagery of war and combat that many, if not most, military professionals hold? I argue that, despite almost two decades of what have been called the "new wars" (Kaldor 2001), the basic image continues to centre on conventional inter-state conflict between soldiers, fought in accordance with the codified laws of war (Munkler 2005:12). Historically, this model reflects the predominant forms of great-power warfare within modern European civilisation (Holsti 1996:13-14) and is the one enshrined in the UN Charter, in collective defence organisations like NATO, and in definitions of aggression in international law. Indeed, notice how terms used by various commentators originate in an assumption that the variety of contemporary conflicts is based on their similarity to, or difference from, conventional wars. Spiller (2000:1), for instance, talks about "war and lesser forms of conflict", and Smith (2000:65) talks about "lesser operations" (presumably contrasted with "greater operations"). Fastbend (1997) mentions "war and military operations other than war" while Gates (1988) talks of "military operations short of war." Or, take the idea of "spectrum of conflict" based on the idea of its intensity (high, medium or low) from which the term LIC (low-intensity conflict) is derived. In fact, the very term "irregular" warfare implies a normal, "regular" war - and assumptions about "regulars" and "irregulars" as fighting adversaries - offering a benchmark against which all other conflicts are almost always measured.

In short, while around the world new kinds of military knowledge is being developed, two elements of continuity are evident. First, many if not all the armed forces still base much of their training, preparation and operation on images of conventional military structures operating in wars that have taken place during the second half of the $20^{\text {th }}$ century. The kind of opponent involved is a peer or near competitor

[and] the defining characteristic of an opponent of this sort of conflict is the possession of conventional forces of a significant size, which could apply to a belligerent in an intra-state conflict. The military tasks involved vary but are largely of a 'force-on-force' character, where combat with the opposing forces is a crucial element and the immediate objectives sought are largely military (Benbow 2004:137). 
Along these lines, the guiding assumptions in much imagery of conventional wars centres on clearly defined and roughly similar opponents, operation of regular (as opposed to irregular) forces, clear lines of territorial domination, quantifiable progression in war, and unambiguous links between military goals and the means to achieve them. Indeed, notice how much attention is now devoted to training and educating soldiers about the "new" conditions of counter-insurgency and the difference from conventional wars and combat. These efforts are indicative of the continued strength of images of conventional wars.

Second, and perhaps more relevant for our analysis, the idealisation of the $20^{\text {th }}$ century's open warfare in which many armed forces participated (or prepared for) and came to form the basis for what Bacevich (2005:45) terms "real soldiering". And it is this kind of soldiering (based on a template of conventional war) that continues to resonate emotionally with most soldiers and officers in terms of participating in "real combat" (Ben-Ari 2004; Ben-Ari 1998) for it still lies at the very core of professional self-images. Such emotional resonance, as a long line of scholars have noted (Robben 2006; Morgan 1994; Badinter 1992; Gilmore 1990; Arkin and Dubrofsky 1978), is related to images of masculinity, to representations in popular culture, and to the expertise of soldiers in the management and effectuation of organised violence. One indirect expression of the power of this imagery, for example, is the difficulties for motivating and allocating prestige to soldiers in peace-related missions. As Burk (1998:42) dryly observes, "One strains to imagine a movie about the 'Blue Helmets' that would rival the 'Green Berets'." Indeed, although there may be differences between militaries in this respect (Sion 2006; Tomforde 2005; Winslow 1997), the template of conventional war (distance from or nearness to "real" combat) continues to resonate emotionally with troops around the world.

These views of "real" soldiering and combat comprise a "folk" model or "lay" theory used by members of professional armed forces to interpret and act upon reality. The term "folk" or "lay" refers to the assumptions and images lying at the base of common-sense military knowledge, the unquestioned knowledge that "everyone knows"; to what Geertz (1983) has termed the "of-courseness" of common-sense understandings. These models are of great importance because they are the basic points of reference for "what we are" and "what we are trying to do" through which military reality is constructed. Indeed, the model of soldiering and combat is used as a template by soldiers and officers to do such things as prescribing proper training, describing and analysing concrete units, or diagnosing actions undertaken by individuals. This deeply resonant model shapes the behaviour of military commanders and soldiers whatever formal military education they have received, and shapes their expectations about armed engagements. 
In this respect, the way enemies are understood within the model of "real" soldiering is of importance. The major "folk" categorisation of enemies - that is, the way soldiers and officers classify different forces they oppose - is based on the threat antagonists pose to oneself, to one's unit, and to the performance of both. Enemies are usually arranged along a gradation of (decreasing) significance: regular armies, militias, organised guerrilla fighters, various irregulars, knife wielders, Molotov cocktail and stone throwers, tire burners and finally to "just" civilians demonstrating. This categorisation of enemies also forms the basis for an informal scale of prestige or stature accorded to an individual or a unit and to society in general. Accordingly, participation in battles in war is more prestigious than participating in armed patrols. Both activities are considered more impressive than policing civilians in an occupation. Underlying this classification is the view that more threatening enemies are more serious. For example, much attention is devoted to understanding the manoeuvrability, capabilities and innovative potential of opposing forces. At the tactical level, commanders frequently comment about the fact that antagonists operate under what they perceive to be their own conditions of uncertainty, and they have their own capacities for reacting to a volatile and threatening environment.

It is in this light that perceptions of child soldiers should be understood. While it is true that "an AK-47 fired by a ten-year-old kills like one fired by a twenty-oneyear-old man", this kind of statement should be placed in context. From a strictly military point of view, as Meijer (2007) is careful to state, the likelihood of facing children as the opposing force is especially pertinent to urban crowd and riot control. We are told that the inexperience and lack of training of such soldiers leave them particularly exposed (United Nations 2002:13). From the military point of view, this is an advantageous situation because child soldiers appear to be easier to combat. In fact, what seems to be the case is that child units are often not cohesive fighting forces, and demonstrative artillery fires (including smoke) and helicopter gunship passes have proven especially effective in shocking and breaking up child soldier forces (Singer 2003:30).

But the problem of course is that the confrontation with child soldiers is not a strictly military problem.

For professional forces, child soldiers present the essential quandary perhaps even more difficult than the issue of civilian casualties. Children are traditionally considered outside the scope of war. Yet now they are potential threats to soldiers' lives and missions (Singer 2003:29). 
11

A major, if unstated assumption at the base of the professional fold mode of "real" soldiering is that enemies are somehow "like us" in that they are rational adults (usually men) with lethal capabilities. In other words, the troops we work with assume that a "proper", "normal" or "accepted" scene of combat is between two clearly defined, regular forces of "adults". It is for this reason that children are outside or at the periphery of the usual system that soldiers use for classifying enemies. The problem hence is that child soldiers are an anomalous category for they are both non-threatening and threatening. Singer (2003:31) warns, "The general public should be aware that the child soldiers armed with AK-47s are just as lethal as are adults." However, for the soldiers facing them this is a problematic proposal. As Meijer (2007), citing a Dutch general who commanded forces in the Congo, states, "On the one hand the engagement with children provokes the provision of safety and care, as on the other hand child warriors produce a life threat, as every other opponent." Child soldiers, in other words, belong to two classification systems and what happens in soldiers' encounters with them is that some very basic (and highly emotionally charged) categories of order and normality are violated. Using violent means against children then contravenes not only certain codes of human conduct against enemies but touches upon some basic understandings about ourselves as human beings.

\section{Moral panics and the new wars}

Our historical circumstances, however, are marked by a rather particular image of children that intensifies and extends the effect of confronting child soldiers. Historically, there are two competing views of childhood in Western societies. Children are seen along the Puritan line of thinking as born sinful with a propensity for evil, or they are seen as innocent and vulnerable. For a variety of reasons, it is the second view that has gained power over the past few decades. The notion of "childhood" as we know it stands in contrast to "adulthood" with children seen as people in the process of becoming, rather than being (James 1993). James and Jenks (1996:318) and Jenks (2005) maintain that in modern times in Western societies (and increasingly around the world) children are set apart temporally and as different through the calculation of age, they are deemed special by nature and determined by biological and psychological forces, and are regarded as innocent and therefore as vulnerably dependent.

The prime popular model of children in the contemporary world developed out of tools provided by developmental psychology. In this psychology, the idea of development - which to us appears commonplace and normal - assumes a path towards a rational, civilised adult as its end-point (Walkerdine 2005:96-7). More 
concretely, child development is seen within this model to be a process of socialisation that follows a predetermined path composed of several stages that children go through on their way to adulthood. In other words, the governing idea of socialisation centres on "childhood as a period in which biological and social forces interact to generate the competent and effective person (individual)" (Boli-Bennett and Meyer 1978:799). Through a variety of processes, this model (and its attendant assumptions) has been globalised (Rogers and Stainton 1992) and taken up in international law, where children's rights have been institutionalised -

"children often appear as presocial and passive recipients of experience who need to be protected up the age of fifteen or eighteen. They need protection, nurturing, and enlightenment, as they are vulnerable, immature, and incapable of assuming responsibilities. Thus, they should be excluded from work and other responsibilities, and confined to the protection of home and school... Children who do not follow this path are considered to be at risk" (Honwana 2001:134).

Innocence, vulnerability and immaturity, in turn, make the link between children and violent acts, such as crime, particularly problematic for they are iconologically irreconcilable: the child murderer is viewed as a transgressive, anomalous creature, a composite child-adult who deviates from accepted norms of childhood (James and Jenks 1996:5). It is the same kind of view that underlies how child soldiers are viewed by professional troops.

Yet the complexity does not end here. In an environment pervaded by fears of world disorder, research centres, think tanks, security experts, and researchers in various disciplines linked to policymakers and decision-makers, journalists and the general public have propagated a view of young soldiers as a veritable scourge.

By firmly linking young humans - especially young men - with violence against states, war researchers and commentators have the potential to instil a sense of moral panic as the 'youth bulge' in parts of the South is seen to pose a grave threat to local, national, regional and even global security concerns (Boyden 2006:2).

The concept of moral panic refers to the reaction of social groups to the false or (more often) exaggerated perception that some kind of behaviour or a group is dangerously deviant and poses a menace to the very basis of social order (Cohen 1972). These reactions are often fuelled by media coverage around a social issue. It is different from mass hysteria in that moral panics are usually expressed as outrage rather than fear. This outrage, in turn, may lead to pressure being placed on leaders, like politicians, to "do something". I suggest, following Boyden (2006), that we are 
witness to something along the lines of an unintended moral panic as regards "child soldiers". Let me provide two sets of examples in the regard. The first set focuses on portrayals of children as the innocent and vulnerable. Even a cursory review of the websites devoted to young soldiers reveals the extent to which visual representations in photographs or drawings are designed to evoke images of blamelessness and helplessness. Or, notice the language that the Human Rights Watch chooses to use:

Physically vulnerable and easily intimidated, children typically make obedient soldiers. Many are abducted or recruited by force, and often compelled to follow orders under threat of death. Others join armed groups out of desperation. ... Children are uniquely vulnerable to military recruitment because of their emotional and physical immaturity. They are easily manipulated and can be drawn into violence that they are too young to resist or understand... Both girls and boys are used as child soldiers. In case studies in El Salvador, Ethiopia, and Uganda, almost a third of the child soldiers was reported to be girls. Girls may be raped, or in some cases, given to military commanders as "wives" (Human Rights Watch, 2007).

One report by the Coalition to Stop the Use of Child Soldiers (2007:1) talks of child soldiers who "have been robbed of their childhood". The International Committee of the Red Cross (2003) uses emotionally mobilising language with such phrases as "child soldiers can be scarred for life, their childhoods shattered", "Every child has the right to a normal childhood, and to develop as a human being", "War crime", and "In the end, child soldiers will suffer deep trauma, which persists long after the fighting has stopped".

The second set of examples links moral stances to threats. Here the sense of moral panic is heightened by the frequent use of "intemperate language that implies mass calamity, as in a report by The Center for Emerging Threats and Opportunities, which describes the phenomenon of child soldiering as a 'Post-Cold War epidemic"'(in Boyden 2006:2). One of the "experts" in the field writing about Iraq pronounces: "Among Iraqi dictator Saddam Hussein's human-rights violations was his policy of recruiting children into Iraq's armed forces, in clear violation of international law and moral norms" (Singer 2003:26), and the title to one section in his article is "Hitler Youth/Saddam Lion Cubs" (Singer 2003:28). Along these lines child soldiers are linked by way of connotation to the Nazi regime.

Notice how all these statements tend to resonate with certain fears cultivated in many societies. Furedi (2002) analyses the moral panic that occurred in the mid-1990s in Britain when a small number of violent acts by children was portrayed as the very 
transformation of childhood in a way that revealed society's anxieties about children. Indeed, "Alongside the 'child labourer', the 'street child,' and the 'child prostitute', the figure of the 'child soldier' has been deployed as a powerful symbol of morally bankrupt societies” (Hart 2006:6).

It is clear that the violence of young people in war is troubling to adults not simply because of the terrible suffering it causes but because it is seen to foreordain societal disorder more generally. This perception calls up parallels with adult reactions to childhood criminality in industrialized countries like the UK. But it would be a mistake to exaggerate these parallels since clearly there is a major difference of scale, for while it is very rare for children in Britain to kill, in societies in conflict young boys and girls are sometimes rendered the prime instruments of violence and terror (Boyden 2006:7).

What marks the attitude of many in such societies as regards contemporary conflicts is what may be termed "a child-focused humanitarianism nourished by sentiments that has grown powerfully over more than a century". Hart (2006:6) refers to this development as the "project of saving children" in which organisations, movements, lobbies and agencies - from the transnational and governmental to the most local - are engaged in the project of saving children as a distinct category of persons under the age of eighteen. These images are carried -produced, propagated and disseminated - by organised cultural or norm entrepreneurs. The prime example in this respect is the Coalition to Stop the Use of Child Soldiers that (we are told)

unites national, regional and international organisations and Coalitions in Africa, Asia, Europe, Latin America and the Middle East. Its Steering Committee members are Amnesty International, Defence for Children International, Human Rights Watch, International Federation Terres des Hommes, International Save the Children Alliance, Jesuit Refugee Service, and the Quaker United Nations Office, Geneva (Coalition to Stop the Use of Child Soldiers 2007).

These human rights organisations and humanitarian movements belong to what may be termed an international civil society, "those networks of activists concerned with human rights, poverty, indigenous rights, emergency aid, ecological justice, gender equity, and other fundamental humanist goals who form non-state networks and interest groups across national boundaries" (Appadurai 2006:131). These networks work by gathering and circulating information, forcing transparency, putting pressure on specific states, and very often by mobilising protest through electronic means. Moreover, the 
human rights regime has become increasingly entrenched "at a global level in international declarations, conventions, and agreements that are negotiated, implemented and monitored by national, international and transnational institutions" (Cowan, Dembour and Wilson 2001:12). What is important regarding these networks of movements and organisations - Colonomos (2006) calls them "moral epistemic communities" - is that their reports are carried by the media, reacted to by politicians, studied by academics and sometimes mobilised into popular power. As Merry (2001:35) explains, over the past fifty years, transnational organisations such as the UN and innumerable non-governmental organisations -

have created a new legal order through transnational processes of information gathering, conferences and discussions under the auspices of the UN and regional bodies... Conventions, treaties and implementation systems are created by international teams, then ratified by states which assume responsibility for enforcing them, with some monitoring by a global body. Even though the human rights system lacks the sanctioning power of state law, its expansion and elaboration creates new discursive legal space within the global arena (Merry 2001:35).

I emphasise the centrality of these coalitions or networks not in order to deny the extremely important role that they are carrying out. Rather, and here I go beyond previous analyses, I do so to underscore how they create emotionally resonant images that often frame understandings of child soldiers that then reverberate with the experience of professional soldiers. That is the reason, I argue, why soldiers who face children in war may be particularly demoralised and vulnerable to a variety of personal and ethical difficulties.

\section{New wars}

However, the complexity of the situation does not end here, for confronting child soldiers and the psychological stress this may entail is related to central characteristics of the "new wars" (Kaldor 2001): those conflicts that often both combine armed struggles with criminal activities and human rights violations. In today's world, following Smith (2006), conflicts are managed and fought through the media, the internet and the stage of (national and global) public opinion. Today's conflicts - and most crucially the interventions of key countries - are judged on television screens and in newspaper columns. In today's world, the media is integral to the strategic level of conflict, not the tactical, since the military and political levels must be able to explain the context and produce a convincing narrative to wider publics. This element is heightened by our specific historical context due both to technological 
innovations allowing instantaneous reporting and the fact that many armed conflicts have become global media events.

This situation is intensified by what Martin Shaw (2005:75-6) calls "global surveillance", the growing transparency of contemporary armed forces to external agents such as political leaders, the media (local and global), the judiciary, pressure groups, international non-state institutions such as the Red Cross, Human Rights Watch or Amnesty International, and individual reports transmitted through cellular phones or the internet (Burk 1998; Dandeker 1998:34). The expanding transparency of the armed forces has been accompanied, in turn, by the expansion of international law governing military activity (Merry 2001). In addition, since children have special rights under warfare there is an added potential here for various kinds of violations. All these trends imply that almost all of the actions of troops are constantly open to external scrutiny, to monitoring. Thus, as any commander of a force participating in a PSO knows, in addition to the usual stresses of such missions, they can go terribly wrong if there are casualties incurred by child soldiers. Singer (2003:29) seems to hint at this point when he mentions, "the public-affairs nightmare that surrounds the use of child soldiers" since killing them may turn them into "heroic martyrs" (Singer 2003:29).

These developments are all related to emerging international norms that involve what have come to be called "wars of conscience". Dandeker (1998:35) suggests that, in late modernity, accompanying a greater questioning of the legitimacy of unilateral use of military force to resolve international disputes is the increased focus on human rights as an addition to the concept of security. What we have been witness to over the past twenty years is the development of new international norms that define what is legitimately accepted by state actors. Certain actors or norm entrepreneurs - domestic and external, state and NGO-based, and often supported by the media - have steadily been pushing to expand the role of humanitarian interventions. These loose coalitions of intellectuals, informed publics, human rights and humanitarian movements, and national and transnational judicial bodies have been producing a global discourse on human rights and the rules and expectations developed within it for the proper initiation and use of force (Colonomos 2006; Ignatieff 1998, 2004; Warren 2000:228).

As a consequence, human rights now provide the very basis for justifying and legitimising military intervention. The power of these global norms, refracted through domestic and international pressure, tends to force Western decision-makers to intervene even when they should not because such norms resonate with assumptions about the responsibility of key countries for conflicts in the Third World and the need to alleviate suffering and poverty among civilians in them. These themes are so ethically and emotionally evocative for they touch, as Ignatieff (1998) observes, on the bases of Western self-perceptions as good, responsible, moral beings. Indeed, they go back to the 
very rhetoric used with regard to the project of "saving the children" and especially child soldiers. As I demonstrated, it is designed to appeal to a combination of moral sensibilities, emotionally charged assumptions about children, and a sense that "something must be done".

As a consequence, as Chandler (2001) and Reiff (2002:243-6) contend, the integration of human rights into humanitarian work has led to the emergence of a militarised humanitarianism. Thus, the "new humanitarianism" has become not only much more explicitly politically involved and committed but has also emerged as a driver for intervention in various places around the world (Minear and Weiss 1995). Perhaps one unintended consequence of this situation has been the appearance of a set of mobilising slogans for new missions as in the calls for Human Security (European Union 2004) or indeed "humanitarian interventions" or "peace-building" (Mychajlyszyn 2000). It is in this light that children at war in general, and child soldiers in particular, form mobilising mottos that are often part of the justification for humanitarian interventions. Indeed, it may well be that "child soldiering" has become one of the iconic images of the current world disorder. It is iconic in the sense of representing in dense form many of the perceived problems of conflict in the contemporary world.

\section{Conclusions}

My aim in this article has been to contextualise the notion of child soldiers rather than treating it as an unproblematic category of young fighters. I have argued that, at the local level of armed conflicts, confronting child soldiers entails an encounter between the emotionally charged professional "folk" model of "real soldiering" that professional troops have and global images of children as innocent and vulnerable. The combination of threatening youngsters and assumptions about their inexperience and immaturity creates a cultural anomaly that poses a set of problems for the soldiers who confront them. I then contended that this situation is ironically intensified (or indirectly exacerbated) by the very actions of a loose coalition of the media, leaders, experts and campaigners for human rights and humanitarian causes. These networks represent child soldiers as embodying the threats and dangers posed by armed conflict and social disorder, and the images and representations they produced then reverberate with the experiences of troops in various PSOs. I then linked my argument to the emergence of a regime of global surveillance of the armed forces and the advent of a new humanitarian militarism that bears directly on issues of child soldiers.

Let me add a final note on the wider implications of my article. During the past decade or so, the number of child soldiers has decreased due (among other causes) 
to the important work of that loose coalition of forces centred on this issue. The thrust of my work has thus not been on naturalising children as soldiers (and therefore turning them into legitimate military targets). Rather, by embedding the children and war relationship in a wider human rights discourse I have attempted to show how one of the unintended consequences of this discourse may actually be the heightening of psychological and ethical difficulties for professional troops.

* I would like to thank three anonymous reviewers for very useful comments on an earlier version of this article, and participants in a NATO roundtable on child soldiers who reacted to a very initial report on which this article is based.

\section{References}

Amnesty International. 2007. Children and Human Rights [Online] Available: http://web.amnesty.org/pages/childsoldiers-index-eng [2007, 23 January].

Appadurai, Arjun. 2006. Fear of Small Numbers: An Essay on the Geography of Anger. Durham, N.C.: Duke University Press.

Arkin, William and Lynne R. Dobrofsky. 1978. Military Socialization and Masculinity. Journal of Social Issues, 34(1):151-68.

Bacevich, Andrew J. 2005. The New American Militarism: How Americans are Seduced by War. Oxford: Oxford University Press.

Badinter, Elisabeth. 1992. XY: On Masculine Identity. New York: Columbia University Press.

Beah, Ishmael. 2007. A Long Way Gone: The True Story of a Child Soldier. London: Harper Perennial.

Ben-Ari, Eyal. 1998. Mastering Soldiers: Conflict, Emotions and the Enemy in an Israeli Military Unit. Oxford: Berghahn Books.

Ben-Ari, Eyal. 1997. Body Projects in Japanese Childcare: Culture, Organization and Emotions in a Preschool. London: Curzon.

Ben-Ari, Eyal. 1998. Mastering Soldiers: Conflict, Emotions and the Enemy in an Israeli Infantry Unit. London: Berghan.

Ben-Ari, Eyal and Galeet Dardashti. 2001. Tests of Soldierhood, Trials of Manhood: Military Service and Male Ideals in Israel, in Daniel Maman, Eyal Ben-Ari and Zeev Rosenhek (eds.). War, Politics and Society in Israel: Theoretical and Comparative Perspectives. New Brunswick, N.J.: Transaction Publishers. 239-68. 
Ben-Ari, Eyal. 2004. Emotional Control, Violence and Soldiering: A Case Study from the Israeli Military, in Myrdene Anderson (ed.). The Cultural Shaping of Violence. West Lafayette: Purdue University Press. 165-178.

Ben-Ari, Eyal, Ze'ev Lehrer, Uzi Ben-Shalom and Ariel Vainer. 2009. Rethinking the Sociology of Combat: Israel's Combat Units in the Al-Aqsa Intifada. Ithaca: State University of New York Press.

Ben-Ari, Michael and Kellen Ben-Ari, Michael and Kellen. 2009. Introduction, in Kobi Michael, David Kellen and Eyal Ben-Ari (eds.). The Transformation of the World of Warfare and Peace Support Operations.Westport Conn.: Praeger Security International.

Benbow, Tim. 2004. The Magic Bullet? Understanding the 'Revolution in Military Affairs'. London: Brassey's.

Boli-Bennet, John and John W. Meyer. 1978. The ideology of childhood and the state: rules distinguishing children in national constitutions. American Sociological Review, 43:797-812.

Brett, Rachel. 2002. Girl Soldiers: Challenging Assumptions. New York and Geneva: Quaker United Nations Office.

Boothby, Neil G. and Christine M. Knudsen. 2000. Children of the Gun. Scientific American, June:40-5.

Boyden, Jo. 2006. Children, War and World Disorder in the $21^{\text {st }}$ Century: A Review of the Theories and the Literature on Children's Contributions to Armed Violence. Oxford: QEH (Queen Elizabeth House) Working Paper Series Number 138.

Boyden, Jo and Joanna de Berry. 2004. Introduction, in Jo Boyden and Joanna de Berry (eds.). Children and Youth in the Front Line: Ethnography, Armed Conflict and Displacement. Oxford: Berghahn. xi-xxvii.

Brett, Rachel and Irma Specht's 2004. Young Soldiers: Why they Choose to Fight. Boulder Colorado: Lynne Reinner Publishers.

Brookings Institute. 2007. Interview P.W. Singer on Child Soldiers. Voice of America, October 30. [On Line] Available http://www.brookings.edu/interviews/ 2002/0425usmilitary_singer.aspx.

Burk, James. 1998. Introduction: Ten Years after the New Times, in James Burk (ed.). The Adaptive Military. New Brunswick, N.J.: Transaction, 1-24. 
Chandler, David. 2001. The Road to Military Humanitarianism: How the Human Rights NGOs Shaped a New Humanitarianism Agenda. Human Rights Quarterly, 23(3):678700 .

Coalition to Stop the Use of Child Soldiers. 2007. Lebanon: The Vulnerability of Children to Involvement in Armed Conflict. [On Line] Available: www.childsoldiers.org [2007, 25 February].

Cohen, Stanley. 1972. Folk Devils and Moral Panics. London: MacGibbon and Kee.

Cohn, Ilene and Guy Goodwin-Gill. 1994. Child Soldiers: The Role of Children in Armed Conflict. Oxford: Clarendon Press.

Colonomos Ariel. 2006. Tying the Gordian Knot: Targeted Killings and the Ethics of Prevention. Paper presented at a conference on The Moral Dimension of Asymmetrical Warfare, organized by The Netherlands Defence Academy in Amsterdam, Oct 2006.

Cowan, Jane K., Marie-Benedicte Dembour and Richard A. Wilson. 2001. Introduction, in Jane K. Cowan, Marie-Benedicte Dembour and Richard A. Wilson (eds.). Culture and Rights: Anthropological Perspectives. Cambridge: Cambridge University Press. 126.

Dandeker, Christopher. 1998. A Farewell to Arms? The Military and the NationState in a Changing World, in James Burk (ed.). The Adaptive Military. New Brunswick: Transaction. 139-161.

Dawes, Andy and Ed Cairns. 1998. The Machel Study: Dilemmas of Cultural Sensitivity and Universal Rights of Children. Peace and Conflict. Journal of Peace Psychology, 4(4):335-48.

European Union 2004 A Human Security Doctrine for Europe: The Barcelona Report of the Study Group of Europe's Security Capabilities. Barcelona: Presented to EU High Representative for Common Foreign Policy and Security Policy, Javier Solana. Fastbend, David. 1997. The Categorization of Conflict. Parameters, Summer:75-87.

Fine, Gary A. 1988. Good Children and Dirty Play. Play and Culture, 1:43-56.

Furedi, Frank. 2002 Culture of Fear: Risk-Taking and the Morality of Low Expectations. London: Continuum.

Gates, John M. 1998. The U.S. Army and Irregular Warfare. [On Line] Available: http://www.wooster.edu/history/jgates/book [2007, August 3]. 
Geertz, Clifford. 1983. Local Knowledge: Further Essays in Interpretive Anthropology. New York: Basic Books.

Ghosh, Amitav. 1994. The Global Reservation: Notes toward an Ethnography of International Peacekeeping. Cultural Anthropology, 9:414-22.

Gibbs, Sarah. 1994. Post-War Reconstruction in Mozambique: Reframing Children's Experience of War and Healing. Disasters, 18(3):268-300.

Gilmore, David, D. 1990. Manhood in the Making: Cultural Concepts of Masculinity. New Haven: Yale University Press.

Hart, Jason. 2006. Saving Children: What Role for Anthropology? Anthropology Today, 22(1):5-8.

Hirschfeld, Lawrence A. 2002. Why Don't Anthropologists Like Children? American Anthropologist, 104(2):611-27.

Holsti, Kalevi J. 1996. The State, War and the State of War. Cambridge: Cambridge University Press.

Honwana, Alcinda. 2001. Children of War: Understanding War and War Cleansing in Mozambique and Angola, in Simon Chesterman (ed.). Civilians in War: A Project of the International Peace Academy. London: Lynne Reinner. 123-42.

Human Rights Watch 2007. Child Soldiers [Online] Available: http://www.hrw.org/campaigns/crp/index.htm [2007, September 12].

Hutchinson, Sharon. 1996. Nuer Dilemmas: Coping with Money, War and the State. Berkeley: University of California Press.

Ignatieff, Michael. 1998. The Warrior's Honor: Ethnic War and the Modern Conscience. London: Chatto and Windus.

Ignatieff, Michael. 2004. The Lesser Evil: Political Ethics in an Age of Terror. Toronto: Penguin.

International Committee of the Red Cross. 2003. Child Soldiers [On Line] Available: www.icrc.org [2007, 12 September].

James, Allison. 1993. Childhood Identities: Self and Social Relationships in the Experience of Childhood. Edinburgh: Edinburgh University Press.

James, Allison and Chris Jenks. 1996. Public Perceptions of Childhood Criminality. The British Journal of Sociology, 47(2):315-32. 
Jenks, Chris. 2005. Constructing Childhood Sociologically, in Mary Jane Kehily (ed.). An Introduction to Childhood Studies. Maidenhead: Open University Press. 77-95.

Kaldor, Mary. 2001. New and Old Wars: Organized Violence in a Globalized Era. London: Polity.

Makinano, Merliza. 2002. Child Soldiers in the Philippines. Featured Paper Number 2. [On Line] Available: http://www.childprotection.org.ph/monthlyfeatures/ mar2k2a.rtf [2008, May 19].

Meijer, Marten. 2007. Transactional Analysis of Child Warriors as the Opposing Force. NATO: Manuscript.

Merry, Sally Engle. 2001. Changing Rights, Changing Culture, in Jane K. Cowan, Marie-Benedicte Dembour and Richard A. Wilson (eds.). Culture and Rights: Anthropological Perspectives. Cambridge: Cambridge University Press. 31-55.

Minear, Richard and Thomas G. Weiss. 1995. Mercy Under Fire: War and the Global Humanitarian Community. Boulder: Westview.

Morgan, David H.J. 1994. Theater of War: Combat, the Military and Masculinities, in Harry Brod and Michael Kaufman (eds.). Theorizing Masculinities. Thousand Oaks: Sage. 165-82.

Munkler, Herfried. 2005. The New Wars. London: Polity.

Mychajlyszyn, Natalie. 2000. Twisting Arms and Flexing Muscles: Perspectives on Military Force, Humanitarian Intervention and Peacebuilding - Report on a Workshop. Carleton University: The Norman School of International Affairs, Occasional Papers Number 21.

Nordstrom, Carolyn. 2004. Shadows of War: Violence, Power, and International Profiteering in the Twenty-First Century. Berkeley: University of California Press.

Rieff, David. 2002. A Bed for the Night: Humanitarianism in Crisis. London: Vintage.

Richards, Paul. 1996 Fighting for the Rainforest: War, Youth and Resources in Sierra Leone. Oxford: James Currey.

Robben, Antonius C.G.M. 2006. Combat Motivation, Fear and Terror in TwentiethCentury Argentinian Warfare. Journal of Contemporary History, 41(2):357-77.

Rogers, Rex Stainton and Wendy Stainton. 1992. Stories of Childhood: Shifting Agendas of Child Concern. New York: Harvester. 
Schafer, Jessica. 2004. The Use of Patriarchical Imagery in the Civil War in Mozambique and its Implications for the Reintegration of Child Soldiers, in Jo Boyden and Joanna de Berry (eds.). Children and Youth in the Front Line: Ethnography, Armed Conflict and Displacement. Oxford: Berghahn. 87-104.

Shaw, Martin. 2005. The New Western Way of War. London: Polity.

Singer, Peter W. 2003. Fighting Child Soldiers. Military Review, May-June:26-31.

Singer, Peter W. 2005. Children at War. New York: Pantheon Books.

Sion, Liora. 2006. “Too Sweet and Innocent for War?” Dutch Peacekeepers and the Use of Violence. Armed Forces and Society, 32(3):454-74.

Smith, Hugh. 2000. The Last Casualty? Public Perceptions of Bearable Cost in a Democracy, in Michael Evans and Alan Ryan (eds.). The Human Face of Warfare: Killing, Fear and Chaos in Battle. London: Allen and Unwin. 54-83.

Smith, Rupert. 2006. The Utility of Force: The Art of War in the Modern World. London: Penguin.

Spiller, R. 2000. Introduction, in Michael Evans and Alan Ryan (eds.). The Human Face of Warfare: Killing, Fear and Chaos in Battle. London: Allen and Unwin. 1-4.

Tomforde, Maren. 2005. Motivation and Self-Image among German Peacekeepers. International Peacekeeping, 12(4):576-85.

United Nations. 2002. Promotion and Protection of the Rights of Children: Impact of Armed Conflict on Children. United Nations: Report of the Expert of the Secretary-General to the General Assembly.

United Nations. 2005. UN Says Use of Child Soldiers Widespread, but Declining. United Nations [On Line] Available: http://www.voanews.com/english/archive/ 2005-02/2005-02-23-voa62.cfm?CFID=151954717\&CFTOKEN=28108262. [2008, 26 June]

Vigh, Henrik. 2006. Navigating Terrains of War: Youth and Soldiering in GuineaBissau. New York: Berghahn.

Vogler, Pia. 2006. "You cannot stop them": Livelihood Strategies of Refugee and Forced Migrant Youth at the Thai-Burma Border. Manuscript. Oxford University.

Waksler, Frances C. 1986. Studying Children: Phenomenological Insights. Human Studies, 9:71-82. 
Walkerdine, Valerie. 2005. Developmental Psychology and the Study of Childhood, in Mary Jane Kehily (ed.). An Introduction to Childhood Studies. Maidenhead: Open University Press. 96-107.

Warren, Kay. 2000. Conclusion - Death Squads and Wider Complicities: Dilemmas for the Anthropology of Violence, in Jeffrey A. Sluka (ed.). Death Squad. Philadelphia: University of Pennsylvania Press, 226-42.

Winslow, Donna. 1997. The Canadian Airborne Regiment in Somalia: A Sociocultural Inquiry. Canada. Minster of Public Works and Government Services. 